\title{
Tourism valorisation of lighthouses on Croatian islands and along the coast
}

\author{
V. T. Opačić ${ }^{1}$, S. Favro ${ }^{2} \&$ M. Perišić ${ }^{3}$ \\ ${ }^{1}$ University of Zagreb, Faculty of Science, Department of Geography, \\ Zagreb \\ ${ }^{2}$ Hydrographic Institute of the Republic of Croatia, Croatia \\ ${ }^{3}$ Split Plovput Ltd, Croatia
}

\begin{abstract}
In the nowadays demanding tourism market Croatia wants to present itself not just as a country of classical "3S (sea, sun and sand)" tourism offer but also as a destination with great potential for the development of a more complex tourism product that would carry a development of high-quality sustainable tourism intended for an individual, more demanding, more educated, well-off and ecologically conscious tourist. "Robinson tourism", in which tourists search isolation and peace in an intact environment, is becoming a very popular type of tourism in the world. Considering stressful living conditions in ecologically more polluted cities with a low life quality, the above mentioned is not a surprise. In order to enrich island and coastal tourism offers in the early 2000s a process of tourism valorisation of lighthouses began mostly on secluded locations of Croatian islands and along the coast. Due to the automation of light-mechanisms on numerous Croatian lighthouses there are less and less lighthouse keepers which opened the possibility to renovate apartments for tourists where once a lighthouse keeper and his family lived. For lighthouse maintenance and its tourism conversion Plovput Ltd. from Split is in charge. The company started this rent a lighthouse project that not only just brings profit but it also provides funds for reconstruction of these cultural heritage monuments built in the $19^{\text {th }}$ century and the first part of the $20^{\text {th }}$ century. Today, due to this project 14 lighthouses have been integrated into this tourism offer. The main aim of this research is to define the characteristics of a Croatian lighthouse accommodation offer as well as the main features of the structure and volume of a tourism flow in 2008.
\end{abstract}

Keywords: lighthouses, heritage, "Robinson tourism", tourism offer, tourism demand, sustainable tourism, Croatian islands. 


\section{The need for the creation of new products in Croatian maritime tourism}

The structural problems related to the tourism of the Croatian littoral had emerged even before the break-up of the former Yugoslavia, i.e. already in the late 1980s, when the formerly predominant concept of the development of the maritime tourism for the masses, with the concomitant over-reliance on the simple and (in common opinion) "spent" tourism product based on natural attractions ("the sun and the sea") became outdated and largely debunked. The implementation was long overdue of the new ideas resulting from the need for the segmentation of the tourism market and for the corresponding redefinition of the concept of tourism development founded on the implementation of the alternative tourism offer aimed at a better-quality tourism product which can satisfy the ever more demanding tourist [11].

The reconstruction of former accommodation capacities in the post-war renewal of Croatian tourism was not sufficient. The whole Croatian coast with islands had to be "discovered anew" as a tourism destination. While the first post-war tourist seasons were dominated by tourists from the Central European post-socialist countries (Hungary, Czech Republic, Slovakia, Poland, with the traditionally significant representation of Germans, Italians, Slovenians and Austrians), the beginning of the new century inaugurated marked changes in the structure of tourists by country of origin: on the increase in the number of tourists from the European West (e.g. the British, French, Dutch, Scandinavians) and even from countries outside of Europe (USA, Israel, Japan), while the proportion of tourists from somewhat lesser-developed Central and Eastern European countries stagnated or slightly decreased, with the exception of Russia whose tourists visit Croatia in greater numbers. The comparison between the structures of foreign tourists in Croatia in 1998 and in 2008 also reveals a greater degree of diversification of emissive tourism markets in Croatian tourism. While in 1998 the tourists from the 15 leading emissive countries realised $97.12 \%$ of all international tourist nights, in 2008 they represented "only" $90.21 \%$ of all international tourist nights in Croatia (Tab. 1).

In the record-breaking 2008 Croatia recorded 11.3 million tourist arrivals (out of which there were 9.4 million international arrivals) and 57.1 million tourist nights (out of which there were 50.6 million international tourist nights). The majority of tourist flow was realised in coastal and island tourism destinations, which confirms the predominance of that part of Croatia in Croatian tourism.

"The sun and sea tourism", which is still the dominant form of tourism in Croatia, binds to itself an increasingly complex tourism offer which presupposes the integration of a variegated range of attractions which support the offer of new tourism products. This is precisely why in the past fifteen years Croatia has tried to re-position the coastal part of Croatia as a tourism destination with a new tourism product, to prolong the season, to open new, smaller family hotels with a higher level of service with the simultaneous arrival of international, reputable hotel chains on the Croatian market, and in this way to achieve a qualitative step forward which will guarantee higher income generated by tourism. An increasing 
Table 1: $\quad$ Foreign tourist nights in Croatia by country of origin in 1998 and 2008.

\begin{tabular}{|c|c|c|c|c|c|}
\hline \multicolumn{3}{|c|}{1998} & \multicolumn{3}{|c|}{2008} \\
\hline COUNTRY & $\begin{array}{l}\text { TOURIST } \\
\text { NIGHTS }\end{array}$ & $\%$ & COUNTRY & $\begin{array}{c}\text { TOURIST } \\
\text { NIGHTS }\end{array}$ & $\%$ \\
\hline Germany & 5933641 & 22,82 & Germany & 10982654 & 21,69 \\
\hline Slovenia & 4035713 & 15,52 & Slovenia & 5802277 & 11,46 \\
\hline Italy & 3669780 & 14,11 & Italy & 5069287 & 10,01 \\
\hline Czech Rep. & 3527934 & 13,57 & Austria & 4164793 & 8,23 \\
\hline Austria & 2871271 & 11,04 & $\begin{array}{c}\text { Czech } \\
\text { Republic }\end{array}$ & 4122460 & 8,14 \\
\hline Slovakia & 1142600 & 4,39 & Poland & 2511568 & 4,96 \\
\hline Poland & 899876 & 3,46 & Netherlands & 2334993 & 4,61 \\
\hline Hungary & 805238 & 3,10 & Hungary & 1933978 & 3,82 \\
\hline Netherlands & 696097 & 2,68 & Slovakia & 1927093 & 3,81 \\
\hline $\begin{array}{c}\text { Bosnia and } \\
\text { Herzegovina }\end{array}$ & 651346 & 2,50 & France & 1635494 & 3,23 \\
\hline $\begin{array}{c}\text { United } \\
\text { Kingdom }\end{array}$ & 410053 & 1,58 & $\begin{array}{c}\text { Russian } \\
\text { Federation }\end{array}$ & 1446776 & 2,86 \\
\hline Belgium & 188274 & 0,72 & $\begin{array}{c}\text { United } \\
\text { Kingdom }\end{array}$ & 1223226 & 2,42 \\
\hline $\begin{array}{c}\text { Russian } \\
\text { Federation }\end{array}$ & 150510 & 0,58 & $\begin{array}{l}\text { Bosnia and } \\
\text { Herzegovina }\end{array}$ & 1198560 & 2,37 \\
\hline France & 144867 & 0,56 & Sweden & 722392 & 1,43 \\
\hline Switzerland & 126588 & 0,49 & Denmark & 594785 & 1,17 \\
\hline $\begin{array}{c}\text { Other } \\
\text { countries }\end{array}$ & 748148 & 2,88 & $\begin{array}{c}\text { Other } \\
\text { countries }\end{array}$ & 4955186 & 9,79 \\
\hline TOTAL & 26001936 & 100 & TOTAL & 50625522 & 100 \\
\hline
\end{tabular}

Sources: Tourism, 1998, Statistical Reports 1078, Central Bureau of Statistics, Zagreb [9]. Tourism, 2008, Statistical Reports 1380, Central Bureau of Statistics, Zagreb [10].

number of elements which make the basis of the Croatian tourism attraction, so far not properly evaluated, contribute to the formation of the image of Croatia as a lifestyle destination with the significant coastal and island tourism product. In order to enrich the tourism offer of the Croatian littoral with marketable and globally innovative products, the first years of the 21 st century witnessed the beginning of the evaluation of the tourism significance of lighthouses, predominantly those located in more isolated locations on Croatian islands and along the coast [1].

\section{Lighthouses as a segment of the attraction basis of the new Croatian tourism product}

In order to retain a competitive edge in an increasingly demanding market, the tourism product increasingly emphasises local identity. As a result, the tourism 
product seeks to integrate elements of natural and cultural heritage. The totality of preserved and protected cultural and natural historical elements is precisely this heritage which needs to be kept for future generations; it is an important element in the protection of local identity, and more and more often is also one of significant pillars of the quality tourism product.

The need for escape from (the working) everyday life manifests itself in the modern tourist also in his or her wish for spending time resting in a peaceful environment of preserved nature in complete contrast to the stressful life of everyday work in the city. Therefore, the point of any tourist trip is found in a temporary change of lifestyle. This increases the attractiveness of destinations which can offer psycho-physical rest to the (over)stressed individual who has an above-average paying capacity, a higher level of education, who is more sensitive to ecological considerations, and who senses a more acute need for isolation in a family setting. Thus, "isolation" and "exclusivity" are notions which are increasingly mentioned in any competitive tourism offer of most forms of tourism, and so also in maritime "sun and sea tourism".

Croatia is one of the rare countries in the world which has, through the integration of lighthouses as objects of accommodation into the tourism offer, succeeded in satisfying these two previously highlighted elements of demand in a contemporary tourism: the search for a local identity and the need for peaceful rest in an ecologically clean, natural environment in exclusive, isolated island and coastal locations. The lighthouses scattered on Croatian islands and along the coast meet the need for the most sought after activity of all tourist travel - the enjoyment in sea water, which, in addition to the above mentioned chief elements of demand, represents a comparative advantage of this Croatian product over that of its competition.

Although a "system of navigation" had existed in the Antique even before the emergence of modern lighthouses, the system which included torches on the tops of the turrets at harbour entrances, lighthouses understood in the modern sense of the word started to be built in the Adriatic only from the beginning of the 19th century when the Austro-Hungarian empire, in an attempt to develop a mighty navy, erected a basic network of lighthouses [4]. In the period between the two World wars, during the time of a Socialist Yugoslavia and in the period of an independent Croatia, the system was supplemented with new lighting objects and technologically modernised. In the time of the Austro-Hungarian empire, a total of 65 lighthouse buildings were built on islands and peninsulas of the Croatian part of the Adriatic for the purposes of navigational orientation - the oldest was built in 1818 on the cape of Savudrija in Istria, and the most recent in 1899. Unfortunately, during the Second World War most of them were damaged or destroyed and many lighthouse keepers were killed or went missing [2].

During the $19^{\text {th }}$ and $20^{\text {th }}$ centuries the lighthouses were inhabited and maintained by generations of lighthouse families. Lighthouses with conspicuous towers and massive stone constructions are located along the whole Adriatic coast on the protruding capes of the Croatian islands and along the coastline [4]. From the time of their erection in the $19^{\text {th }}$ century the lighthouses were maintained by generations of lighthouse families. The automation of the 
lighthouses in the 1990s, the constant link with fast ships, powerboats, and the introduction of satellite navigation in maritime traffic significantly diminished the need for lighthouse families. As a result the lighthouse buildings have lost their former function of navigational orientation points and accommodation units [5].

Although lighthouses are considered cultural-historical monuments, the modest budgets of the respective Croatian ministries did not provide sufficient funds for the maintenance of these objects which were severely eroded through the influence of the sea and climactic factors.

\section{The "Stone Lights" project}

Since the state of Croatia failed to procure funds needed for the maintenance of the lighthouses after their automation, the burden of their maintenance fell on the firm Plovput Ltd. from Split. "Plovput Ltd. Split" is a company owned by the Republic of Croatia which is responsible for the upkeep of waterways in the inner sea waters and the territorial sea of the Republic of Croatia. It is also responsible for the construction and maintenance of objects pertaining to sea travel security which includes, among others, maritime lighthouses. Towards the end of the 1990s Plovput Ltd. initiated the project called "Stone Lights" which is based on the adoption of positive experiences in the lighthouse preservation and the integration of history, ecology and tourism. The purpose of the project was to commercialise lighthouse buildings through their conversion into apartment buildings, which would secure the means for their preservation as culturalhistorical monuments and their revitalisation through this new activity. The integration of the lighthouses into the wider tourism offer would not present an obstacle to their primary purpose, that is, provision of security and protection of maritime travel, nor would it have a negative impact on the life of the existing lighthouse keepers (e.g. on Palagruža Island) [2, 3].

The main goal was to determine the potential for commercial (for-profit) exploitation of lighthouses based on market-related arguments in relation to their size, overall condition, bedding capacity, location, attractiveness of the building, necessary investments, cost-effectiveness and such like. Thus Plovput Ltd. started with the gradual integration of relevant objects into the overall tourist activity.

Between 2001 and 2009 the total of 14 lighthouses were included into the tourism offer, with a further 28 lighthouses which will still be converted to accommodation units. The first among them is Korčulanske sestrice on an islet in the Pelješac channel, and Grebeni on the rock of the same name just in front of Dubrovnik (2010) as well as Zaglav on the rock of the same name before the west coast of the island of Cres and Stražica on the island of Prvić south of the island of Krk (2011) (Fig. 1).

All 48 lighthouse objects in Croatia cover the total area of $10398 \mathrm{~m}^{2}$. Out of this $83 \%$ represents space designated as accommodation, and $17 \%$ represents ancillary objects. This confirms the claim that lighthouses represent significant tourism potential on very attractive locations [3]. 


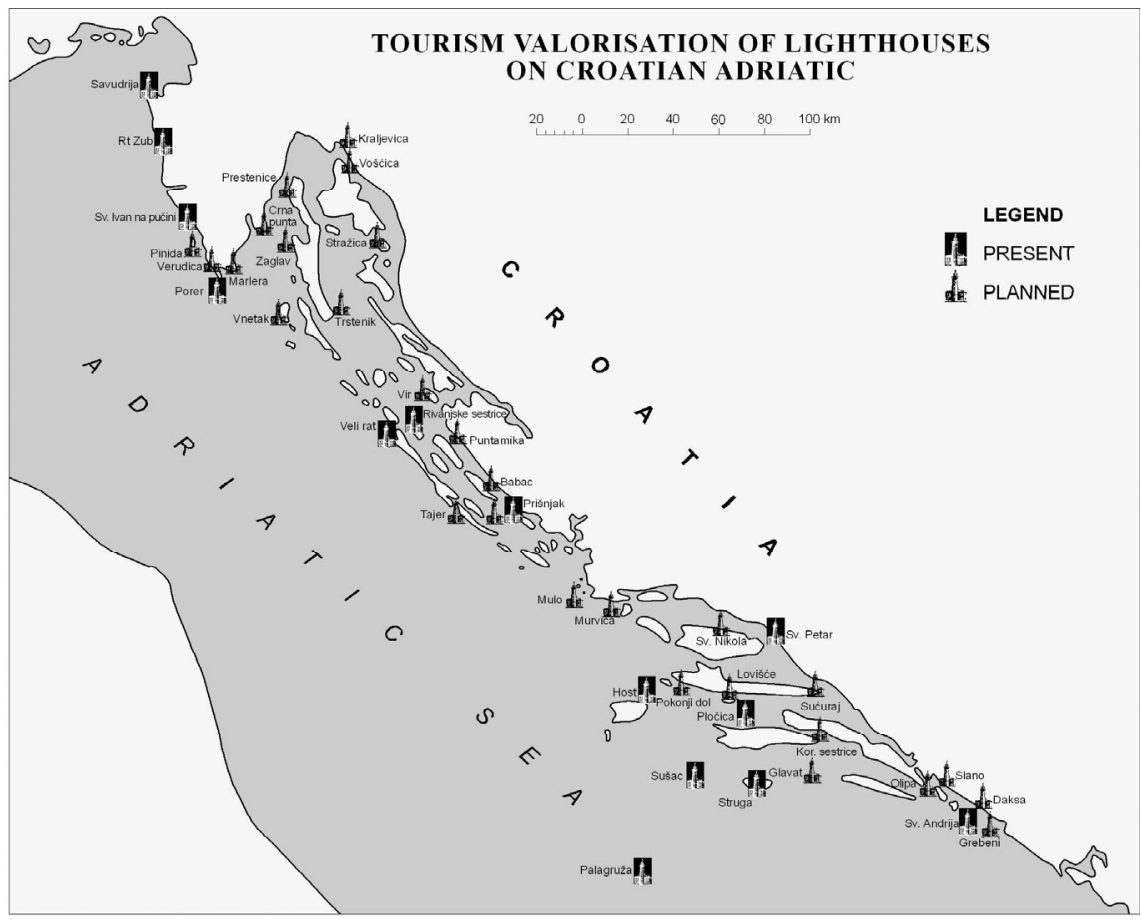

Figure 1: Lighthouses in the Croatian tourism offer.

Although the lighthouses included in the tourism offer differ from each other with respect to their attractiveness, size, the number of apartments, the vicinity of tourism destinations and transportation infrastructure, one of the most significant presuppositions of the success of their tourism valorisation is certainly their location. Lighthouse objects can be classified in three groups according to the characteristics of their location [2].

a) Lighthouses on isolated, uninhabited open sea islands

b) Lighthouses on inhabited islands outside of island settlements

c) Lighthouses on the mainland in the vicinity of coastal settlements

The lighthouses on isolated, mostly uninhabited open sea islands are located on distant islets and rocks and for the most part offer isolation to the fans of "Robinson tourism". They make dreams of one's own island come true. The tourists can savour the rich offer of the sea; they can go fishing or diving to explore the undersea world. These islands are visited by those tourists who appreciate the magic of the unbridled open sea wilderness. This group of lighthouses which have been converted for tourism purposes includes the following lighthouses: Sveti Ivan na pučini and Porer on an islet in front of the west coast of Istria, Rivanjske sestrice on an islet near the island of Rivanj, Prišnjak on an islet near the island of Murter, Pločica on the island of the same name in the channel of Korčula, between the islands of Korčula and Hvar, Host on the islet of the same name at the entrance to the Vis harbour, Sušac on the 
island of the same name west of Lastovo, Palagruža on the island of the same name in the most distant Croatian group of islands in the Adriatic, and Sveti Andrija on the islet of the same name west of Dubrovnik (Fig. 1).

Lighthouses on inhabited islands outside of island settlements suit those tourists who in addition to isolation, swimming, fishing and diving wish to have the opportunity to visit inhabited locations. In that way they can obtain their food daily, and they also have the opportunity to become acquainted with the life and customs of the local population. These lighthouses support the development of the nautical tourism offer and quickly become favourite destinations of the growing number of nautical tourists. Two such lighthouses are integrated into the tourism offer: Veli rat in the offer of Dugi otok and Struga in the offer of the island of Lastovo (Fig. 1).

Lighthouses on the mainland in the vicinity of coastal settlements are old attractive buildings which offer comfortable stay in the lighthouses to their guests, i.e. a in somewhat more isolated locations in the relatively turistificated coast, pleasant beaches, but also in the amenities of the tourism offer and other services of the neighbouring larger urbanised settlements on the coast. Since these lighthouses are located on the mainland, the tourists can use of their own cars to arrive there, as well as for sightseeing and visits to natural and anthropological attractions in the nearer and farther surroundings. The lighthouses located in the vicinity of coastal settlements which are used for tourist purposes are: Savudrija on the cape of the same name on the west coast of Istria, Rt Zub between Novigrad and Poreč on the west coast of Istria and Sveti Petar on the cape of the same name in Makarska (Fig. 1).

\section{The tourism offer and tourism flow in Croatian lighthouses}

Croatian lighthouses converted for the purposes of tourist accommodation offer a total of 23 apartments with 97 rooms. In 2009 the apartments in lighthouses were categorised with three stars, two stars and one star, which leads to the conclusion that this kind of accommodation is primarily aimed at "Robinson tourists" who seek, above all, peaceful rest in the isolation of secluded locations, while the quality of accommodation is only of secondary consideration (Tab. 2).

All apartments in lighthouses have similar outfitting in keeping with the postulates of sustainable tourism in the sensitive island surroundings [7, 8]. Larger electricity users of electric energy (fridges, stoves and deep freezers) work on the propane-butane cylinders which does away with the need for the use of energy units running on liquid fuel. Other electricity users in apartments include TV sets and special lighting devices which use energy-saving light bulbs. The device shared by all apartments is a pump which draws water from the reservoir and brings it to the loft level of the building whence it is distributed further by the use of natural gravitational pull. All electricity users which cannot be connected to the public electricity network draw energy from the independent system of solar panels and batteries with the possibility of subsequent additional energy supply from the generators using ecologically clean wind energy [2]. 
Table 2: Croatian lighthouses in tourism offer - the number of apartments (APT), number of beds, categorisation, the year of construction, the year of the inclusion in tourism offer of accommodation.

\begin{tabular}{|c|c|c|c|c|c|}
\hline $\begin{array}{l}\text { LIGHT- } \\
\text { HOUSE }\end{array}$ & $\begin{array}{l}\text { NUMBER } \\
\text { OF APT }\end{array}$ & $\begin{array}{l}\text { NUMBER } \\
\text { OF BEDS }\end{array}$ & CAT. & $\begin{array}{c}\text { YEAR OF } \\
\text { CONSTRUCTION }\end{array}$ & $\begin{array}{c}\text { FIRST } \\
\text { YEAR OF } \\
\text { USE FOR } \\
\text { TOURISM } \\
\text { PURPOSES } \\
\end{array}$ \\
\hline Host & 1 & 3 & $* *$ & 1873 & 2006 \\
\hline Palagruža & 2 & 8 & $* * *$ & 1875 & 2001 \\
\hline Pločica & 2 & 14 & $* * *$ & 1887 & 2002 \\
\hline Porer & 2 & 8 & $* * *$ & 1833 & 2001 \\
\hline Prišnjak & 1 & 4 & $* * *$ & 1886 & 2001 \\
\hline $\begin{array}{c}\text { Rivanjske } \\
\text { sestrice }\end{array}$ & 1 & 3 & $* *$ & 1899 & 2007 \\
\hline Rt Zub & 1 & 6 & $* * *$ & 1872 & 2001 \\
\hline Savudrija & 1 & 4 & $* * *$ & 1818 & 2001 \\
\hline Struga & 4 & 14 & $* * *$ & 1839 & 2002 \\
\hline Sušac & 2 & 8 & $* * *$ & 1878 & 2001 \\
\hline Sveti Andrija & 1 & 6 & * & 1873 & 2001 \\
\hline $\begin{array}{l}\text { Sveti Ivan na } \\
\text { Pučini }\end{array}$ & 2 & 8 & $* * *$ & 1853 & 2001 \\
\hline Sveti Petar & 1 & 4 & $* *$ & 1884 & 2001 \\
\hline Veli Rat & 2 & 7 & $* *$ & 1849 & 2001 \\
\hline TOTAL & 23 & 97 & & & \\
\hline
\end{tabular}

The tourism activity of the lighthouses is organised in four time-periods in four corresponding price-classes. In 2009 the pre-season lasted from 30th May to 4th July, full season from 5th July to 30th August, post-season from 30th August to 20th September, while the rest of the year was defined as the out-of-season period, but also with organised tourism activities in the lighthouses. The minimal duration of rent in the season, pre-season and post-season is one week, while outof-season it is possible to make a booking for a minimum of three days (except in the most distant lighthouses on Palagruža and Sušac Islands). Out of season it is possible to make a booking for shorter periods of a minimum three days. An additional (fourth) day is charged by the price-list, and the stay of 5 to 7 days is charged at the price of one week. Due to the strong demand for weekend tourists 
also in the out-of-season period the Istrian lighthouses Sveti Ivan na pučini and Porer allow short stays of a duration of at least two days [2].

The price of renting a lighthouse includes accommodation in the corresponding apartment and alternative accommodation in case of an inability to access the island lighthouse on account of prohibitive weather conditions. Victuals are responsible for their own supplies. Most lighthouses offer the possibility of renting a boat and organising excursions in co-ordination with the lighthouse keepers (Sv. Ivan na Pučini, Veli rat, Sušac, Palagruža, Struga) or with persons in charge of transportation (Porer, Pločica, Prišnjak). The transportation to the lighthouse on the island of Palagruža is provided by Plovput Ltd. while the transportation to other lighthouses is organised by third persons. The lighthouses provide strong signal for the operation of mobile telephones [2].

Information about the tourist booking of lighthouses leads to the conclusion that the proximity to and the accessibility of the coast are still among the most important determinative factors of their tourism utilisation. It is evident, namely, that the apartments located on the mainland (Savudrija, Rt Zub, Sveti Petar) or on inhabited islands (Veli rat on Dugi otok, and to some degree also Struga on Lastovo) record higher utilisation than the lighthouses on the distant open-sea uninhabited islands, particularly those farthest from the mainland, for example the lighthouse on the island of Palagruža. The different utilisation rates with respect to the categorisation of apartments in lighthouses have not been observed, which yet again confirms the thesis that location and not the interior outfitting is the decisive factor of the tourism flow in the lighthouses (Tab. 3).

The demand for tourist stay in Croatian lighthouses is strongest among Italian tourists (about $50 \%$ of tourists in lighthouses), as well as among tourists from the German-speaking countries (Germans, Austrians, Swiss - about 20\% of tourists in lighthouses) and from the former Central and Eastern European Socialist countries (about $20 \%$ of tourists in lighthouses), while domestic tourists represent slightly less than $10 \%$ of tourists in lighthouses. The interest in renting apartments in lighthouses is increasing. It is also worth mentioning that there is significant interest in lighthouse tourism also outside the "bathing season", which confirms the proposition that many tourists are motivated by the wish to experience life on a "desolate island", i.e. to feel as lighthouse keepers, and not only by the search for isolation during the "bathing season".

The costs related to the renting of apartments in lighthouses are relatively high because their distance from the mainland considerably increases all expenses. The objects located on the mainland are connected to the municipal water supply which keeps the cost of water supply lower. In some lighthouses the utility-related expenses reach $50 \%$ of the overall income, while on objects located on the mainland these expenses can be as low as $15-20 \%$ of the overall income.

Objects offered for rent are burdened with the cost of outfitting, investment and regular maintenance, transportation costs and staffing costs. The cost of maintenance is particularly high because the sea foam causes rapid deterioration of inventory. This increases the depreciation rate which in turn decreases profit. After eight years of involvement in tourism business which Plovput Ltd. has had so far, and on the basis of the completed analysis of income and outcome, it is 
Table 3: The tourism flow in apartments (APT) of Croatian lighthouses in 2008.

\begin{tabular}{|c|c|c|c|c|c|}
\hline APT & $\begin{array}{c}\text { NUMBER OF } \\
\text { BEDS }\end{array}$ & $\begin{array}{c}\text { TOTAL } \\
\text { OCCUPANCY } \\
\text { (NUMBER OF } \\
\text { DAYS) }\end{array}$ & $\begin{array}{c}\text { TOTAL } \\
\text { NUMBER OF } \\
\text { REALISED } \\
\text { TOURIST } \\
\text { NIGHTS }\end{array}$ & $\begin{array}{c}\text { POTENTIAL } \\
\text { NUMBER OF } \\
\text { TOURIST } \\
\text { NIGHTS }\end{array}$ & $\begin{array}{c}\text { OCCU- }- \\
\text { PANCY } \\
(\%)\end{array}$ \\
\hline \multicolumn{6}{|c|}{ LIGHTHOUSES ON ISOLATED, UNINHABITED OPEN SEA ISLANDS } \\
\hline Palagruža A1 & 4 & 97 & 388 & 732 & $53 \%$ \\
\hline Palagruža A2 & 4 & 56 & 224 & 732 & $31 \%$ \\
\hline PločicaA1 & 6 & 102 & 612 & 1098 & $56 \%$ \\
\hline Pločica A2 & 8 & 73 & 584 & 1464 & $40 \%$ \\
\hline Porer A1 & 4 & 63 & 252 & 732 & $34 \%$ \\
\hline Porer A2 & 4 & 86 & 344 & 732 & $47 \%$ \\
\hline Prišnjak & 4 & 150 & 600 & 732 & $82 \%$ \\
\hline Sušac A1 & 4 & 194 & 506 & 732 & $69 \%$ \\
\hline Sušac A2 & 4 & 92 & 368 & 732 & $50 \%$ \\
\hline Sveti Andrija & 6 & 40 & 240 & 1098 & $22 \%$ \\
\hline $\begin{array}{c}\text { Sveti Ivan na } \\
\text { pučini A1 }\end{array}$ & 4 & 81 & 324 & 732 & $44 \%$ \\
\hline $\begin{array}{l}\text { Sveti Ivan na } \\
\text { pučini A2 }\end{array}$ & 4 & 79 & 316 & 732 & $43 \%$ \\
\hline TOTAL & 56 & 1113 & 4758 & 10248 & $46 \%$ \\
\hline \multicolumn{6}{|c|}{ LIGHTHOUSES ON INHABITED ISLANDS OUTSIDE OF ISLAND SETTLEMENTS } \\
\hline StrugaA1 & \begin{tabular}{|l|}
2 \\
\end{tabular} & 106 & 212 & 366 & $58 \%$ \\
\hline Struga A2 & 3 & 122 & 366 & 549 & $67 \%$ \\
\hline Struga A3 & 4 & 73 & 292 & 732 & $40 \%$ \\
\hline Struga A4 & 5 & 46 & 230 & 915 & $25 \%$ \\
\hline Veli rat $\mathrm{A} 1$ & 4 & 182 & 728 & 732 & $99 \%$ \\
\hline Veli rat A2 & 3 & 148 & 444 & 549 & $81 \%$ \\
\hline TOTAL & 21 & 677 & 2272 & 3843 & $59 \%$ \\
\hline \multicolumn{6}{|c|}{ ISLANDS ON THE MAINLAND IN THE VICINITY OF COASTAL SETTLEMENTS } \\
\hline Rt Zub & \begin{tabular}{|l|}
6 \\
\end{tabular} & 139 & 834 & 1098 & $76 \%$ \\
\hline Savudrija & 4 & 158 & 632 & 732 & $86 \%$ \\
\hline Sveti Petar & 4 & 109 & 436 & 732 & $60 \%$ \\
\hline TOTAL & 14 & 406 & 1902 & 2562 & $74 \%$ \\
\hline $\begin{array}{l}\text { GRAND } \\
\text { TOTAL }\end{array}$ & 91 & 2196 & 8932 & 16653 & $54 \%$ \\
\hline
\end{tabular}

possible to assess the economic effects of the tourism valorisation of Croatian lighthouses. The income realised in 2007 was about 222000 Euro and the outcome about 185000 Euro, which gives a profit of about 37000 Euro. Considering the value of investment into the outfitting of tourist apartments, the period needed for the return of funds invested is very long and cost-effectiveness low. The reason for this is because Plovput Ltd. needs this profit for covering part of the costs related to the maintenance of maritime lighthouses $[2,6]$. 


\section{Conclusion}

In 2001 the firm Plovput Ltd. from Split initiated the conversion of lighthouse buildings on more remote Croatian islands and along the coast into objects suitable for tourist accommodation. One of the underlying reasons was the fact that the automation of lighthouses resulted in the shrinking of the crews which manned lighthouses, which in turn caused lighthouses to be abandoned and left to decay. Through the "Stone Lights" project lighthouses have been incorporated into the tourism offer. This ancillary activity brings Plovput Ltd., the firm in charge of the maintenance of lighthouses, necessary funds for the maintenance and revitalisation of the lighthouse buildings which are invaluable also as monuments of cultural heritage which had been built in the $19^{\text {th }}$ century in the period of the Austro-Hungarian empire, as well as lighthouses in their own right in their primary function of providing safety for the shipping traffic.

So far 14 lighthouses have been converted on Croatian islands and the coast. They offer 23 apartments categorised with one, two or three stars, with a total of 97 beds. In the conversion and process of the lighthouses great attention was paid to the sustainable development within the sensitive island environment.

The lighthouses are found in three different groups of locations in relation to their distance from the mainland: lighthouses on isolated, uninhabited open sea islands; lighthouses on inhabited islands outside island settlements, and lighthouses on the mainland in the vicinity of coastal settlements. Each group of locations offers a different tourism product and possibilities.

Although the bulk of the tourist activity is concentrated in the summer months when the chief purpose for the stay in the lighthouses is bathing on "one's own" island or on the isolated parts of the mainland, tourists have also shown interest outside of the main tourist season which supports the thesis that the isolation which lighthouses offer is a key motive irrespective of the time of the year.

The analysis of the tourist activity in the lighthouses has concluded that the proximity and the accessibility of the coast are still among the key determining factors of their tourism utilisation. It has been determined that the lighthouse utilisation rate diminishes in proportion to the distance between the lighthouse and the mainland or larger, inhabited islands. This is also corroborated by the fact that the closer and more accessible islands enjoy a longer tourist season, and that these lighthouses are more fully booked out of season than are those lighthouses located on smaller and uninhabited islands of the open sea. There is no difference in relation to the categorisation of the lighthouse apartments, which supports the claim that location and not the level of outfitting is a key factor for the tourism activity in the lighthouses.

Tourists interested in this tourism product mostly come from Italy, Germanspeaking countries (Germany, Austria, Switzerland), former Central and Eastern European Socialist countries, while domestic demand is much more modest.

Although the cost-effectiveness of the project of the integration of lighthouses into the tourism accommodation offer is relatively small, and the period of the return of the invested funds long and uncertain, it is already manifest that the tourism evaluation enabled the preservation of the Croatian lighthouses as 
heritage monuments, which is, in addition to the maintenance of the objects which provide security for shipping traffic, in the long term the most important positive outcome of this project.

\section{References}

[1] Opačić, V. T. (2005): Svjetionici hrvatskoga turizma http://www.geografija.hr/clanci/693/svjetionici-hrvatskoga-turizma

[2] Perišić, M. (2009): Lighthouses as a part of tourist offer being specific tourist destination, Interdisciplinary Management Research V, editor Dražen Barković, University of Osijek, Croatia, 381-395

[3] Šerić, N. (2003): Ekološki turistički projekt Kamena Svjetla - čuvari lanterni povijesnih vrijednosti, Jadranska meteorologija, No 48, 74-80

[4] Šerić, N. (2004): Kamena svjetla - priče $i$ legende o jadranskim svjetionicima, o mjestima na kojima su izgrađeni i o njihovom podmorju, Marjan tisak, Split

[5] Šerić, N. (2005): Objekti pomorske signalizacije i svjetioničarska služba u Republici Hrvatskoj, Jadranska meteorologija, No 50, 48-57

[6] Šerić, N. (2008): Realizacija II faze složenog investicijskog projekta Kamena svjetla - sanacija i revitalizacija svjetioničarskih zgrada bez ljudske posade, Gospodarstvo i okoliš, No 16, 3-9

[7] Šerić, N. (2008): Upravljanje otpadnim higijenskim vodama na jadranskim svjetionicima, Hrvatska vodoprivreda, No 17, 59-63

[8] Šerić, N., Ikač, M., Vidović, Z. (2002): Disposal of waste water in ecologically sensitive environment of lighthouses, Zbornik radova ELMAR - editor Tomislav Kos, Zadar, 135-140

[9] Tourism, 1998, Statistical Reports 1078, Central Bureau of Statistics, Zagreb, 1999

[10] Tourism, 2008, Statistical Reports 1380, Central Bureau of Statistics, Zagreb, 2009

[11] Vlahović, D. (2003): Maritimna turistička Hrvatska, Ogranak Matice hrvatske Split, Matica hrvatska, Split-Zagreb 